UDC 81'255.2:001

DOI https://doi.org/10.32841/2409-1154.2020.46-1.37

Karachun Yu. H.,
Candidate of Philological Sciences,
Associate Professor at the Department of Theory, Practice and Translation of English
National Technical University of Ukraine "Igor Sikorsky Kyiv Polytechnic Institute"

Borkovska I. P., Candidate of Philological Sciences, Associate Professor at the Department of English for Humanities № 3 National Technical University of Ukraine "Igor Sikorsky Kyiv Polytechnic Institute"

\title{
MAIN CATEGORIES OF ENGLISH SCIENTIFIC AND TECHNICAL TEXTS ON ELECTRICAL ENGINEERING
}

Summary. The research is devoted to the concept of "scientific and technical text" from the standpoint of socio-historical, structural-semantic, functional-semantic, socio-communicative, pragmatic, cognitive approaches.

It was revealed that the concept of scientific and technical text can be considered and modeled through the prism of text categories. Today, in the stream of modern linguistic research, foreign and Ukrainian scholars have repeatedly turned to the analysis of text categories. However, nowadays there is no similar answer on the question: "What text categories are typical for scientific and technical texts on electrical engineering?". Having considered a significant number of classifications, only those text categories that are characteristic of the analyzed literature were generalized and analyzed: scientific and educational textbooks, scientific articles, technical contracts and technical instructions on electrical engineering. Among the main ones we distinguish: cohesion, which is manifested through external structural indicators, through the formal dependence of text components, through the implementation of logical connections between depicted objects, phenomena, facts or processes in electrical engineering; integrity (coherence), which consists in its defined logical and semantic structure, where there is a close relationship between the components; informativeness, which consists in the ability of the text to be a carrier of the completed message and a channel for transmitting and providing society with information, which in turn will encourage communication; articulation, the possibility of such a text to be divided into separate text fragments so that the compositional and syntactic structure of the scientific and technical text was clear to the recipient of information; completeness is considered as the sufficiency of the textual form and volume of the material, which is determined by a sufficient number of syntactic structures to cover this topic in accordance with the communicative purpose and intentions of the author of the text; consistency in the scientific and technical text is realized in the use of functional-syntactic means for logical transition from one opinion to another, from gradual delivery of research results to society and gradual summarization of conclusions that contribute to convincing substantiation of facts and evidence; pragmatism is expressed by the author's choice of optimal language means for successful delivery of information, to facilitate its understanding by the recipient, by deploying the material in a logical sequence to achieve pragmatic goals of communication with the reader / listener, which facilitates the addressee's influence on the recipient.
Key words: scientific and technical text, electrical engineering, text category, cohesion, coherence, informativeness, structure, completeness, pragmatism.

Formulation of the problem. Today, in the era of information technology and scientific and technical achievements, not only scientific discovery but also its successful transmit to the public is of great importance. Acquaintance of the audience with the results of scientific research is often due to scientific and technical literature. Scientific and technical text, in particular on electrical engineering, is created in the process of scientific research in this field, the implementation of theoretical and practical scientific and technical developments, the implementation of the results in production. Thus, there is a need to analyze scientific and technical literature, especially to define its main categories that determine the topicality of chosen topic of the research.

Analysis of the latest researches and publications. Scientific and technical text is studied by functional stylistics, which studies the features of language norms in accordance with the scientific style; linguistic pragmatics, which analyzes the purpose of communication participants, as well as a person's attitude to their own and others' speech; linguistics of the text, which explores the norms of construction, structural and stylistic features of scientific and technical text; psycholinguistics, which clarifies the processes of language creativity, perception and formation of speech and the correlation of these processes with the language system.

Modern linguistic studies focus on structural, semantic and pragmatic peculiarities of scientific and technical text, the main works are: E. Aznaurova, F. Batsevych, I. Bekhta, M. Brandes, Dzh. Braun, N. Valhina, A. Vezhbitska, T. Drozdova, N. Enkvist, O. Yemets, T. Yeshchenko, Zh. Alzheo, A. Zahnitko, T. Zuienko, N. Ishchenko, M. Kautkhard, V. Kozlovskyi, N. Kravchenko, V. Kukharenko, T. Maslova, A. Matvieieva, I. Naumenko, T. Radziievska, O. Selivanova, Z. Turaieva, O. Sheihal and others. Since in linguistics there is no single view on texts' categories and their quantity, we consider this problem controversial and unresolved issues.

Formulation of goal and tasks of the research. The goal of the research is to define and analyze main categories of English scientific and technical texts on electrical engineering.

Formulated object led to the task solving, such as:

- focus on such concept as "scientific and technical text"; 
- define and analyze main categories of English scientific and technical texts on electrical engineering.

Object of the research - are English scientific and technical texts on electrical engineering: instructions, contracts, manuals, articles.

Subject of the research - are main categories of scientific and technical texts on electrical engineering in the English language.

The material of the research are 10296 pages of science and technical literature: (15 manuals, 9725 pages), 15 scientific articles (160 pages), 15 technical contracts ( 70 pages) and 15 technical instructions (341 pages).

Main material. Analysis of general theoretical material showed that scientists considered the scientific and technical text from such standpoint as:

- socio-historical approach, according to which the scientific and technical text is defined as a written product that represents the results of intellectual and scientific activities of society in different eras of its existence;

- structural-semantic approach, according to which the scientific and technical text is a statement that is characterized by a set of consistently interconnected phrases and completeness;

- functional and semantic approach, according to which the scientific and technical text is considered as a complete semantic unity due to the semantic and functional relationships of the elements of the text;

- socio-communicative approach, according to which the scientific and technical text is defined as a complex communicative mechanism, where the text is a product of scientific activity and a mediator of speech (communicative) activity between the speaker and the recipient of information;

- pragmatic approach, according to which the scientific and technical text is considered as a means of socio-psychological influence on the recipient, because according to 0 . Yemets [1], N. Ishchenko [2] communication in the scientific environment and beyond is carried out mainly through the text, which is able to some extent to influence the consciousness of the recipient and motivate him to certain actions;

- cognitive approach, according to which the scientific and technical text is considered as a way of cognition under the influence of certain socio-pragmatic factors.

Having considered and analyzed the multifaceted interpretation of the scientific and technical text from the standpoint of socio-historical, structural-semantic, functional-semantic, socio-communicative, pragmatic approaches, an attempt is made to generalize it in own definition of this concept.

Thus, the scientific and technical text is an ordered structural-semantic, compositional-stylistic and functional-pragmatic unity, united by different types of lexical, logical, grammatical connections, which represents the results of human scientific activity, serves as a means of transmitting scientific information, which are implemented in accordance with the motive, purpose, chosen topic, idea and audience.

Functional approach to the study of scientific and technical text has led to the actualization of the problem of text categories that reflect the most essential and general properties, features and stages of its ontological, epistemological and structural features. However, there is no single view on their number, status and hierarchy. We share the opinion of M.M. Kozhina [3] that the text category is a mandatory system-forming feature, which determines the scientific and technical text.

Currently, there is significant number of classifications of text categories, varying depending on the author and style, background and genre of texts.

S. Tycher considered the scientific and technical text as a holistic communicative statement with a certain set of categorical features (text categories), namely: coherence (cohesion), integrity (coherence), linearity, informativeness, acceptability, intertextuality, situationality and completeness [4]. L. Matsko divided the categories of scientific and technical text into two groups: semantic and structural. The researcher referred to the first as informativeness, completeness, communicativeness, integrity, and to the second - integration, coherence, linearity and structure [5, p. 33-34]. I. Kovalyk believed that the main categories of the text include coherence, intertextuality, informativeness, communicativeness, linearity, integrity, structure and structural and semantic completeness [6]. V. Kukharenko believed that every scientific and technical text must have such categories as structure, cohesion (cohesion), integrity (coherence), anthropocentricity, conceptuality, informativeness, systematics, integrity, modality, pragmatism and focus [7, p. 74]. According to L. Matsko, the most important categories are coherence, integrity, structure, linearity, informativeness, completeness [5].

Having considered the main text categories, we consider it expedient to generalize and allocate common and defining for the scientific and technical text of electrical engineering, which include cohesion, coherence, informativeness, structure, completeness, pragmatism, because such categories allow us to consider the scientific and technical text as a system of higher rank, because it is modeled only by their totality.

English scientific and technical text can be characterized by a clear structural combination of phrases in sentences, sentences in paragraphs, paragraphs in paragraphs, paragraphs in sections, etc., it is in this manifestation of the category of coherence, through the implementation of logical connections between the depicted objects, phenomena, facts or processes in electrical engineering.

A feature of scientific and technical text on electrical engineering of modern English is the presence of semantic similarity between syntactic structures, where each previous sentence is a necessary element in the formation of the next, where each subsequent event is due to the previous one. The category of coherence of scientific and technical text is a phenomenon of structural, semantic and communicative integrity, having relations: form, content, function.

Any scientific and technical text has certain types of coherence: structural and semantic coherence (by which we mean words, phrases close in meaning, grammatical and stylistic units, forms and categories) and semantic (based on events and the development of the topic, content).

However, the question of defining the types of cohesion, their number and systematization in modern linguistics has not found an unambiguous solution, because the scientific and technical text is not only informational and structural unity, but also a functionally complete linguistic whole. Based on the scientific work of Z. Turaeva [8], N. Fairclough [9], an attempt was made to distinguish the following classification types of cohesion:

- formal-grammatical coherence is based on the use of conjunctions, pronouns, adverbs, articles, numerals, adjective inversions; 
- the semantic coherence of the scientific and technical text is expressed through the repetition of common seven connected words;

- onomasiological connection with the characteristic repetition of word-forming (derivational) components of complex terminological units;

- semantic coherence is based on the involvement of the mechanism of logical connections of text units, which is expressed in causal relations between the elements of the whole text, in the development of induction and deduction of scientific and technical text;

- structural-compositional coherence of the scientific and technical text presupposes the conformity of the compositional organization to a certain style, which ensures the homogeneity and harmony of the content;

- stylistic connection with the use of metaphors as word-forming elements of complex noun terms that arise from the similarity of external features (size, shape, consistency, appearance) and by functional analogy;

- reference coherence is characterized by the correlation of the text fragment with reality, for example, the conclusions of scientific research and the presentation of its results in the text fragment;

- figurative cohesion is based on associations previously obtained in different ways: visual, auditory or tactile;

- pragmatic coherence of scientific and technical text is focused on interactivity, compliance of motives to achieve and conditions of realization of its understanding.

After analyzing the main types of coherence in the scientific and technical text, we can conclude that they are all aimed at ensuring its integrity (coherence). The category of integrity (coherence) is another of the leading features of the scientific and technical text, which consists in its definite logical and semantic structure, where there is a close relationship between the components. In modern linguistics there are:

- structural coherence, which is characterized by the integral design of scientific and technical text, its internal organization, the semantic unity of its elements, the transition from one part of the text to another with the help of certain language units;

- semantic coherence, which consists in the unity of the theme, which is the core of the entire scientific and technical text;

- communicative coherence, based on the consistent expression of thoughts, actions, results in the next syntactic structure, based on the communicative plan, on the previous syntactic structure, thus forming a thematic chain, which has a final character.

The author of the scientific and technical text chooses the topic himself; determines the scope and sequence of presentation of the material in accordance with the specified topic; determines the degree of disclosure and coverage of details in accordance with the topic, etc. Given the presence and totality in the scientific and technical text of all the above points, we can say that the scientific and technical text is complete, because the completeness of the scientific and technical text is considered as the sufficiency of text form and volume of material that determine sufficient syntactic structures to cover this topic in accordance with the communicative purpose and intentions of the author of the text.

Only after the recipient processes the text message, determines the degree of sufficiency of information to meet their communication needs, he can talk about the degree of its completion. The semantic aspect of the completeness of the scientific and techni- cal text can be determined through the percentage of disclosure of the topic chosen by the author.

We consider the division (structure) of a scientific and technical text as the possibility of such a text to be divided into separate text fragments in order for the compositional and syntactic structure of the scientific and technical text to be clear to the recipient of information. To do this, within each part of the text is divided into paragraphs, sections, subsections, paragraphs, sub-paragraphs, paragraphs, parts, etc., which are autosemantic units, because in their absence there are difficulties in perceiving and understanding the information encoded in it. However, such a division is conditional, because each specified passage of text requires reliance on the entire scientific and technical text.

Structure in a scientific and technical text can be expressed in four ways:

- graphic, when the author uses various graphic symbols for convenient classification of the material: parentheses, quotation marks, numbering;

- grammatical, when the author uses insert constructions in a complex syntactic structure for a more detailed description; contract parts of complex syntactic construction; connectors: connecting, opposite;

- lexical, when the author uses monosyllabic words or repetitions of lexical units within one context;

- compositional, when the author divides the scientific and technical text into separate fragments: syntactic constructions, paragraphs, paragraphs, sub-paragraphs, sections, subsections, paragraphs, etc. [10].

Since the main task of any scientific and technical text is the accumulation, storage and transmission of information in the field of science and technology, we can talk about its informativeness (communicativeness), which is the ability of the text to be a carrier of the completed message and information transmission channel which in turn will encourage communication.

The category of informativeness is responsible for the amount of information (whether this information is enough for scientific communication), for its content (how logically and consistently presented information), for its relevance (how important the information is for further research or able to satisfy, provide the reader / listener with necessary facts in the field of science), for novelty (how new are the results of scientific research), for accessibility (how uncomplicated and understandable the information is for the recipient), for reliability (how true and correct are the results of scientific research), for usefulness (how the results of scientific experiments can be used in further explorations or applications).

The category of sequence in the scientific and technical text is realized in the use of functional-syntactic means for logical transition from one thought to another, from gradual delivery of research results to society and gradual summarization of conclusions that contribute to convincing substantiation of facts and evidence.

Scientific and technical text, like any other text, is not devoid of pragmatics, because the author wants it to be better understood by the reader / listener, but if such principles are absent, then the essence of language communication is violated [11].

The pragmatic category of scientific and technical text is expressed by the author's choice of optimal language means for successful delivery of information, to facilitate its understanding by the recipient, by deploying the material in a logical sequence to achieve pragmatic goals of communication with the reader / listener. 
Thus, scientific and technical text serves to accumulate, generalize, represent the results of research branches serve different genres of scientific style texts, which is a means of implementing theoretical and applied scientific and technical developments.

All categories in this literature are extremely important, because only their combination models the whole definition of the concept of scientific and technical text.

\section{References:}

1. Ємець О.В. Максима кількості як критерій прагмастилістичного аналізу тексту. Філологічні науки: зб. наукових праць. 2014. Вип. 18. С. 89-94.

2. Іщенко Н.Г. Науково-технічний стиль у системі функціональних стилів. Наукові записки нац. ун-ту «Острозька академія». 2014. Вип. 46. С. 78-80.

3. Кожина Н.М. Стилистика русского язика. Москва : Флинт, 2008. $464 \mathrm{c}$.

4. Тичер С. Методы анализа текста и дискурса. Харьков : Гуманитарный центр, 2009. 356 с.

5. Мацько Л.І. Стилістика української мови. Київ : Вища школа, 2003. 462 c.

6. Ковалик І.І., Мацько Л.І., Плющ М.Я. Методика лінгвістичного аналізу тексту. Київ : Вища школа, 1984. 417 с.

7. Кухаренко В.А. Інтерпретація тексту. Вінниця : Нова книга, 2004. $272 \mathrm{c}$.

8. Тураева 3.Я. Лингвистика текста. Москва : Флинт, 1986. 127 с.

9. Fairclough N. Discourse and text: linguistic and intertextual analysis within discourse analysis. Discourse and Society. 1992. № 3. P. 192-217.

10. Радзієвська Т.В. Текст як засіб комунікації. Київ : інститут української мови НАНУ, 1998. 194 с.

11. Іщенко Н.Г. Жанрова палітра наукової комунікації. Наукові записки. 2014. Вип. 42. С. 67-69.

Карачун Ю. Г., Борковська І. П. Основні категорії англомовного науково-технічного тексту з електричної інженерії

Анотація. Наукову статтю присвячено висвітленню поняття «науково-технічний текст» із позицій соціально-історичного, структурно-семантичного, функційно-смислового, соціокомунікативного, прагматичного, когнітивного підходів. У процесі дослідження з'ясовано, що поняття «науково-технічний текст» можна розглядати та моделювати через призму текстових категорій. Сьогодні у річищі сучасних лінгвістичних досліджень зарубіжні та вітчизняні науковці звертаються до аналізу текстових категорій. Проте одностайної відповіді на запитання про те, які ж саме категорії властиві для науково-технічних текстів 3 електричної інженерії, ми не знаходимо. Розглянувши значну кількість класифікацій, нами узагальнено та проаналізовано лише ті текстові категорії, що $є$ характерними саме для аналізованої літератури: науково-навчальні підручники, наукові статті, технічні контракти та технічні інструкції з електричної інженерії. Серед основних виділяємо: зв'язність (когезію), що має вияв через зовнішні структурні показники, через формальну залежність компонентів тексту, через реалізацію логічних зв'язків між зображуваними предметами, явищами, фактами чи процесами в електричній інженерії; цілісність (когерентність), що полягає у визначеній логіко-смисловій структурі тексту, де наявний тісний взаємозв'язок між складниками; інформативність, що характеризується у здатності тексту бути носієм завершеного повідомлення та каналом передавання й забезпечування суспільства інформацією, що спонукатиме до комунікації; членування як можливість такого тексту бути поділеним на окремі текстові фрагменти, щоб композиційно-синтаксична структура науково-технічного тексту була зрозумілою для отримувача інформації; завершеність як достатність текстової форми та обсягу матеріалу, що визначають достатньою кількістю синтаксичних структур для висвітлювання зазначеної теми відповідно до комунікативної мети та намірів автора тексту; послідовність як використання функційно-синтаксичних засобів для логічного переходу від однієї думки до іншої, від поступового доставляння результатів наукового дослідження до суспільства та поетапного підсумовування висновків, які сприяють переконливому обгрунтовуванню фактів та доказів; прагматичність, виражену вибором автора оптимальних мовних засобів для успішного доставляння інформації, для полегшення ії розуміння реципієнтом за допомогою розгортання матеріалу в певній логічній послідовності для досягнення прагматичних цілей свого спілкування $з$ читачем/слухачем, що полегшує вплив адресанта на адресата.

Ключові слова: науково-технічний текст, електрична інженерія, текстові категорії, зв'язність (когезія), цілісність (когерентність), інформативність (комунікативність), членування (структурованість), завершеність, прагматичність. 